\title{
Vitamins and Minerals for Migraine Prophylaxis: A Systematic Review and Meta-analysis
}

\author{
George N. Okoli, Rasheda Rabbani, Hessam H. Kashani, \\ Aleksandra K. Wierzbowski, Christine Neilson, Behzad Mansouri, \\ Ryan Zarychanski, Ahmed M. Abou-Setta
}

\begin{abstract}
Objective: To summarize the findings of randomized controlled trials (RCTs) on the efficacy and safety of vitamins and minerals for migraine prophylaxis. Methods: We systematically searched bibliographic databases and relevant websites for parallel and crossover RCTs reporting efficacy and/or safety of vitamins and/or minerals for migraine prophylaxis. Our primary outcomes were migraine frequency (number of attacks) and duration (hours). Secondary outcomes were severity (intensity), days with migraine, and adverse events. Meta-analysis was conducted when analyzable data were available from at least two trials. Results: Eighteen placebocontrolled trials met our eligibility criteria. Only coenzyme Q10 and magnesium contributed to meta-analyses. In adults, compared with placebo, coenzyme Q10 did not significantly decrease migraine frequency (mean difference (MD) -0.44 ( -2.14 to 1.26 ); $I^{2} 53 \% ; 2$ trials; 97 participants; moderate strength of the evidence), duration (MD -1.97 ( -4.82 to 0.87 ); $I^{2} 0 \% ; 2$ trials; 97 participants; moderate strength of the evidence), or severity (ratio of means (RoM) -0.05 ( -0.20 to 0.11$) ; I^{2} 0 \% ; 2$ trials; 97 participants). In adults, compared with placebo, magnesium did not significantly decrease migraine severity (RoM -0.17 ( -0.36 to 0.02 ); $I^{2} 48 \% ; 3$ trials; 226 participants; low strength of the evidence). Meta-analysis of other vitamins and minerals, and other outcomes were not feasible due to a lack of sufficiently reported data. Conclusions: Based on insufficient evidence, it is unknown if coenzyme Q10 and magnesium are effective for migraine prophylaxis in adults. High-quality, adequately powered RCTs are needed to fully evaluate the efficacy and safety of vitamins and minerals for migraine prophylaxis.
\end{abstract}

RÉSUMÉ: Des vitamines et des minéraux pour traiter de façon préventive la migraine : une revue systématique et une méta-analyse. Objectif: Résumer les résultats d'essais randomisés contrôlés (ERC) portant sur l'efficacité et la sécurité des vitamines et des minéraux dans le traitement préventif de la migraine. Méthodes: Nous avons passé en revue de façon systématique les bases de données bibliographiques et les sites Internet jugés pertinents afin d'identifier des ERC parallèles et transversaux faisant état de l'efficacité et/ou de la sécurité des vitamines et/ou des minéraux dans le traitement préventif de la migraine. Nos principaux résultats thérapeutiques ont concerné la fréquence des migraines (nombre de crises) ainsi que leur durée (nombre d'heures). Les résultats thérapeutiques secondaires ont porté quant à eux sur l'acuité (l'intensité) des crises, sur le nombre de jours durant lesquels les patients étaient aux prises avec la migraine et sur les effets indésirables. Fait à noter, nous avons effectué une méta-analyse dans la mesure où des données analysables étaient disponibles à partir d'au moins deux ERC. Résultats: Au total, dix-huit essais contrôlés par placebo ont satisfait à nos critères d'admissibilité. Seuls la coenzyme Q10 (CoQ10) et le magnésium ont pu contribuer à nos méta-analyses. Par rapport aux individus à qui l'on avait administré un placebo, la CoQ10 n'a pas diminué de façon notable la fréquence de crises migraineuses chez des sujets adultes (différence moyenne ou DM de $-0,44$ [-2,14 à 1,26]; I2 $53 \%$; 2 ERC ; 97 participants ; fiabilité modérée des preuves), leur durée (DM de - 1,97 [- 4,82 à 0,87]; I2 $0 \%$; 2 ERC ; 97 participants ; fiabilité modérée des preuves) ou leur acuité (rapport de moyennes ou RM de - 0,05 [- 0,20 à 0,11]; I2 $0 \%$; 2 ERC; 97 participants). Par rapport aux individus à qui l'on avait administré un placebo, le magnésium n'a pas permis de diminuer de façon importante l'acuité des migraines chez des sujets adultes (RM de - 0,17 [- 0,36 à 0,02] ; I2 $48 \%$; 3 ERC ; 226 participants ; faible fiabilité des preuves). Enfin, il n'a pas été possible d'effectuer une méta-analyse des autres vitamines et minéraux et d'évaluer leurs résultats potentiels en raison d'un nombre insuffisant de données publiées. Conclusions: Faute de preuves suffisantes, on ignore toujours si la CoQ10 et le magnésium sont efficaces en ce qui regarde le traitement préventif de la migraine chez les adultes. Des ERC de grande qualité et suffisamment alimenté en données demeurent ainsi nécessaires afin d'évaluer pleinement l'efficacité et la sécurité des vitamines et des minéraux dans le traitement préventif de la migraine.

Keywords: Migraine, Minerals, Vitamins, Efficacy, Adverse effects, Systematic review

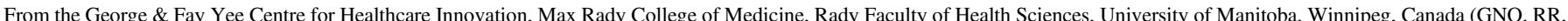

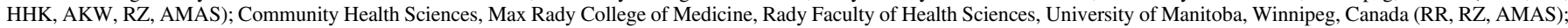

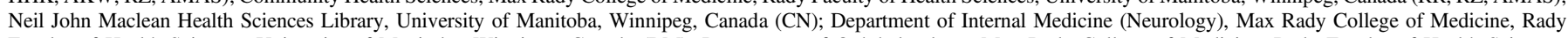

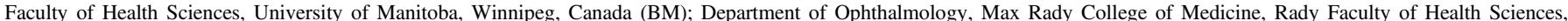

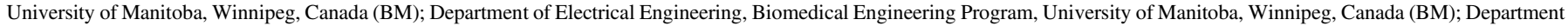
of Hematology and Medical Oncology, CancerCare Manitoba, Winnipeg, Canada (RZ)

Received October 17, 2018. Final Revisions Submitted December 14, 2018. Date of Acceptance December 17, 2018.

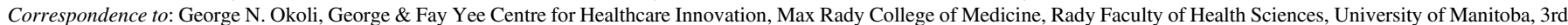
Floor - 753 McDermot Avenue, Winnipeg, MB R3E 0T6, Canada. Email: George.Okoli@umanitoba.ca 


\section{INTRODUCTION}

Pharmacotherapy with prescription medications is widely used for migraine prophylaxis and treatment. The complexity and associated adverse effects of most of the available medications pose a significant challenge to physicians, patients, and their families. The efficacy of many of the available prophylactic migraine medications is also questionable and the evidence base supporting them seems incomplete. ${ }^{1}$ While structured education and careful attention to lifestyle and varied dietary, physiological, and environmental migraine triggers are highly important and advocated, there is growing evidence to suggest that some vitamins and minerals may be effective as prophylaxis against developing migraine attacks. ${ }^{2-6}$ Magnesium, for example, is essential for the activity of many enzymes in the body and plays an important role in neurotransmission and muscular excitability. ${ }^{7}$ Vitamin B2 (riboflavin) is an important component of mitochondrial energy production and membrane stability believed to reduce the frequency of some migraine attacks; thus, it can reduce the incidence of migraine attacks and help control migraine symptoms when an attack does occur. ${ }^{8}$

Vitamins and minerals can be sourced naturally or commercially manufactured from artificial sources. In most cases, they have little or no adverse effects, except in large, non-therapeutic doses (e.g. hypervitaminosis). ${ }^{9}$ Given the adverse event profile and cost of prescription migraine medications, vitamins and minerals may prove to be an appealing alternative option for migraine patients.

The objective of this review is to identify, critically appraise, and meta-analyze data on the efficacy and safety of available over-the-counter vitamins and minerals in reducing the incidence and severity of migraines.

\section{Methods}

We undertook a systematic review and meta-analysis in accordance with the Methodological Expectations of the Cochrane Intervention Reviews (MECIR) guidelines ${ }^{10}$ and reported as per the Preferred Reporting Items for Systematic Reviews and Meta-analysis (PRISMA) guidelines. ${ }^{11} \mathrm{We}$ registered the systematic review protocol with the University of York Centre for Reviews and Dissemination international prospective register of systematic reviews (PROSPERO) prior to executing our literature search (Registration number: CRD42017071440).

\section{Population, Interventions, Comparators, Outcomes, Study Designs (PICOS)}

We considered all parallel and crossover randomized controlled trial (RCT) designs reporting efficacy and/or safety of commercially available vitamins and/or minerals (excluding herbs/herbal supplements) for migraine prophylaxis in adult ( $\geq 18$ years) and pediatric ( $<18$ years) patients. We defined our study population as average-risk individuals (no history of head trauma or neurological disease), irrespective of health status, with a history of migraines. We scoped the literature to identify evidence on vitamins and minerals that have been shown to be effective, and developed the following list of interest to this review: vitamin A (retinol), vitamin B1 (thiamine), vitamin B2 (riboflavin), vitamin B3 (niacin), vitamin B6 (pyridoxine), vitamin B12 (cobalamin), vitamin C (ascorbic acid), vitamin D (cholecalciferol), vitamin E (tocopherol), calcium, iron, magnesium, phosphate, selenium, zinc, and coenzyme Q10 (CoQ10 or Ubiquinone). ${ }^{2,4-6} \mathrm{We}$ considered RCTs in which the intervention was administered in the form of a tablet, capsule, suspension, or injection (irrespective of dose and frequency of administration), and the comparator was a placebo or no treatment (active agents were excluded). Our primary outcome measures were migraine frequency (number of attacks) and duration of migraine episodes (hours). Secondary outcomes were migraine severity (intensity), days with migraine, and migraine-associated adverse events.

\section{Trial Identification}

We utilized a search strategy developed by a knowledge synthesis librarian $(\mathrm{CN})$ and peer-reviewed by an independent professional librarian using the Peer Review of Electronic Search Strategies (PRESS) checklist. ${ }^{12}$ Search results were limited to humans and RCTs using a modified version of the Scottish Intercollegiate Guidelines Network (SIGN) filter for RCTs. ${ }^{13} \mathrm{We}$ applied no other limits to the search results. The initial search was designed using MEDLINE (Ovid) (Supplementary Table 1). After peer review, it was adapted for the following bibliographic databases: Embase (Ovid), Cochrane Central Register of Controlled Trials (Wiley), PsycINFO (ProQuest), and CINAHL with Full Text (EBSCO). The search was last updated in June 2017. In order to identify ongoing or unpublished trials, we supplemented the bibliographic database search with a search of clincialtrials.gov, the World Health Organization International Clinical Trials Registry Platform (ICTRP), and the International Federation of Pharmaceutical Manufacturers Associations (IFPMA) website. The reference lists of included trial publications were mined for additional citations. We also used Scopus (Elsevier) to conduct a forward citation search of the included trial publications and to identify additional citations for potential inclusion in the review.

Identified citations were imported into a specially designed Microsoft (MS) Access 2016 database (Microsoft Corporation, Redmond, WA, USA) for screening. Two reviewers (GNO, AKW or HHK) screened the citations against the eligibility criteria using a two-stage sifting approach (screening of the titles/abstracts and full-text articles). Disagreements during the screening stages were resolved by discussion between the two reviewers or by involving a third reviewer. We recorded the number of ineligible citations at the title/abstract screening stage and both the number and reason for ineligibility at the full-text article screening stage.

Two reviewers (GNO, AKW or HHK) independently extracted data from the included trials using data extraction forms developed in MS Access 2016 database (Microsoft Corporation, Redmond, WA, USA) and piloted on a small selection of trials prior to use for data extraction. Disagreements were resolved by discussion between the two reviewers or by involving a third reviewer. For crossover trials, we only included data before the crossover. We extracted trial information, trial population 


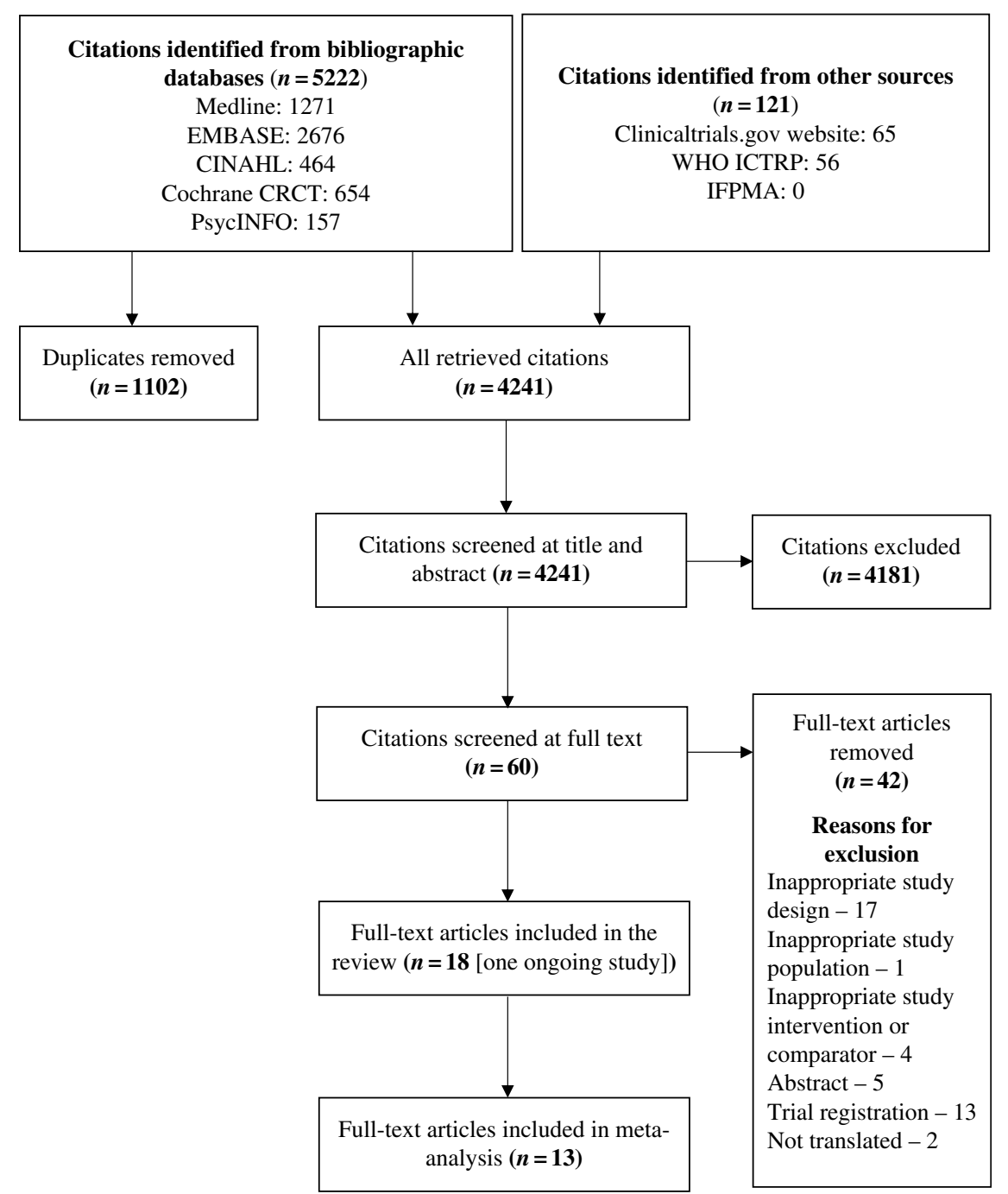

Figure 1: Summary of literature search and screening process (PRISMA flow diagram). Cochrane $C R C T=$ Cochrane Register of Controlled Trials; WHO ICTRP $=$ World Health Organization International Clinical Trials Registry Platform; IFPMA = International Federation of Pharmaceutical Manufacturers Associations.

characteristics, information regarding interventions and comparators, outcomes assessed and results, and details relevant to the risk of bias assessment.

\section{Risk of Bias Assessment}

Two reviewers (GNO, AKW or HHK) independently assessed the risk of bias in each of the included trials at both the trial and outcome levels in compliance with the MECIR guidelines, using the Cochrane Risk of Bias tool. ${ }^{14}$ Disagreements were resolved by discussion between the two reviewers or by involving a third reviewer.

\section{Data Synthesis and Analysis}

Where possible, we conducted meta-analyses using inverse variance, random effects models implemented in RevMan (version 5.3.5), ${ }^{15}$ and we used STATA (version 13; StatCorp LP, Texas, USA) to assess publication bias with Egger's regression test. Meta-analysis was conducted when analyzable data were available from at least two trials. Pooled estimates of effects were calculated using mean differences (MD) and odds ratio (OR); $95 \%$ confidence intervals $(95 \% \mathrm{CI})$ were reported as well for all analyses. In cases where continuous measures of the same outcome were reported with different scales, we used the ratio of means (RoM). If data were presented as medians, we contacted study authors for the mean and standard deviation (SD). If we did not receive a response, then we estimated the mean and SD from the median, range, and the sample size. ${ }^{16} \mathrm{We}$ also assessed and quantified statistical heterogeneity between included trials using the $I$-squared statistic $\left(I^{2}\right) .{ }^{17}$ Publication bias was assessed visually using funnel plots, and using Egger's regression test. ${ }^{18}$

We conducted subgroup analyses for migraine severity, frequency, duration, and days with migraine to describe differences between trials according to risk of bias (low, unclear, or high), vitamin or mineral types, age groups $\geq 18$ years versus $<18$ years, industry- versus non-industry-funded trials, and different outcome measurement tools. Other subgroup analyses that were not possible are available in our PROSPERO protocol. ${ }^{19}$ 
Table 1: Characteristics of included trials

\begin{tabular}{|c|c|c|c|c|c|}
\hline Trial and Country & $\begin{array}{c}\text { Trial Design } \\
\text { (Funding Source) }\end{array}$ & Trial Population (Percentage of males) & $\begin{array}{l}\text { No. of } \\
\text { Patients }\end{array}$ & $\begin{array}{c}\text { Interventions Compared } \\
\text { (Frequency and } \\
\text { Duration) }\end{array}$ & $\begin{array}{l}\text { Outcomes } \\
\text { Assessed }\end{array}$ \\
\hline $\begin{array}{l}{ }^{*} \text { Khorvash et al. }(2016)^{21} \\
\text { Iran }\end{array}$ & $\begin{array}{l}\text { Parallel RCT } \\
\text { (Non-industry funded) }\end{array}$ & $\begin{array}{l}\text { Patients (16-52 years) with migraine (with or } \\
\text { without aura) of more than 1-year history, and } \\
\text { outcome confirmed by a neurologist } \\
(16.7 \%)\end{array}$ & 54 & $\begin{array}{l}30 \text { mg Coenzyme Q10 vs. } \\
\text { Placebo } \\
\text { (Twice daily for } 2 \text { months) }\end{array}$ & $\begin{array}{l}\text { Migraine severity, } \\
\text { frequency, and duration }\end{array}$ \\
\hline $\begin{array}{l}\text { Menon et al. }(2016)^{22} \\
\text { Australia }\end{array}$ & $\begin{array}{l}\text { Parallel RCT } \\
\text { (Non-industry funded) }\end{array}$ & $\begin{array}{l}\text { Female Caucasian patients ( } 18-60 \text { years) with } \\
\text { current diagnosis of migraine (with aura }>90 \% \text { of } \\
\text { attacks), and }>5 \text { years history and family history } \\
\text { of migraine } \\
(0 \%)\end{array}$ & 300 & $\begin{array}{l}\text { Multivitamin (1 mg folic } \\
\text { acid and } 25 \mathrm{mg} \text { vitamin } \\
\text { B6 and } 400 \mu \mathrm{g} \text { B12) vs. } \\
\text { Placebo } \\
\text { (Once daily for } 6 \text { months) }\end{array}$ & $\begin{array}{l}\text { Migraine severity, } \\
\text { frequency, and } \\
\text { associated disability }\end{array}$ \\
\hline $\begin{array}{l}{ }^{*} \text { Mottaghi et al. }(2015)^{23} \\
\text { Iran }\end{array}$ & $\begin{array}{l}\text { Parallel RCT } \\
\text { (Non-industry funded) }\end{array}$ & $\begin{array}{l}\text { Migraine patients (10-61 years), and outcome } \\
\text { confirmed by a neurologist } \\
(27.7 \%)\end{array}$ & 77 & $\begin{array}{l}50,000 \mathrm{IU} / \text { week of } \\
\text { vitamin D vs. Placebo } \\
\text { (Once daily for } 10 \text { weeks) }\end{array}$ & $\begin{array}{l}\text { Migraine severity, } \\
\text { frequency, and duration }\end{array}$ \\
\hline $\begin{array}{l}{ }^{*} \text { Sadeghi et al. }(2015)^{24} \\
\text { Iran }\end{array}$ & $\begin{array}{l}\text { Parallel RCT } \\
\text { (Non-industry funded) }\end{array}$ & $\begin{array}{l}\text { Migraine (with aura) patients ( } 30-65 \text { years) with } \\
\text { at least one attack per month and }>5 \text { years } \\
\text { history of migraine } \\
(20.4 \%)\end{array}$ & 66 & $\begin{array}{l}40 \text { mg vitamin B6 vs. } \\
\text { Placebo } \\
\text { (Twice daily for } 12 \text { weeks) }\end{array}$ & $\begin{array}{l}\text { Migraine severity, } \\
\text { frequency, and duration }\end{array}$ \\
\hline $\begin{array}{l}{ }^{*} \text { Gaul et al. } 2015^{25} \\
\text { Germany }\end{array}$ & $\begin{array}{l}\text { Parallel RCT } \\
\text { (Industry funded) }\end{array}$ & $\begin{array}{l}\text { Healthy migraine patients ( } 18-65 \text { years) with } \geq \\
\text { three migraine attacks per month in the last } \\
\text { three months before recruitment } \\
(13.4 \%)\end{array}$ & 130 & $\begin{array}{l}400 \mathrm{mg} \text { vitamin } \mathrm{B} 2,600 \mathrm{mg} \\
\text { magnesium, and } 150 \mathrm{mg} \\
\text { coenzyme Q10 vs. } \\
\text { Placebo } \\
\text { (Twice daily for } 3 \text { months) }\end{array}$ & $\begin{array}{l}\text { Migraine severity, adverse } \\
\text { events, and days with } \\
\text { migraine }\end{array}$ \\
\hline $\begin{array}{l}\text { Menon et al. }(2012)^{26} \\
\text { Australia }\end{array}$ & $\begin{array}{l}\text { Parallel RCT } \\
\text { (Non-industry funded) }\end{array}$ & $\begin{array}{l}\text { White women ( } 18-60 \text { years), of European } \\
\text { ancestry, diagnosed with migraine (with aura } \\
90 \% \text { of their migraine attacks), with }>5 \text { years } \\
\text { history, and a family history } \\
(0 \%)\end{array}$ & 245 & $\begin{array}{l}\text { Multivitamin (2 mg folic } \\
\text { acid, } 25 \mathrm{mg} \text { vitamin B6, } \\
\text { and } 400 \mathrm{mg} \mathrm{B} 12 \text { ) vs. } \\
\text { Placebo } \\
\text { (Once daily for } 6 \text { months) }\end{array}$ & $\begin{array}{l}\text { Migraine severity, } \\
\text { frequency, and } \\
\text { associated disability }\end{array}$ \\
\hline $\begin{array}{l}\text { *Tarighat Esfanjani et al. } \\
(2012)^{27} \\
\text { Iran }\end{array}$ & $\begin{array}{l}\text { Parallel RCT } \\
\text { (Non-industry funded) }\end{array}$ & $\begin{array}{l}\text { Migraine (with or without aura) patients (18-55 } \\
\text { years), with at least two attacks per month } \\
(20.3 \%)\end{array}$ & 139 & $\begin{array}{l}500 \mathrm{mg} \text { magnesium vs. } \\
\text { Placebo } \\
\text { (Once daily for } 12 \text { weeks) }\end{array}$ & $\begin{array}{l}\text { Migraine severity, } \\
\text { frequency, and days with } \\
\text { migraine }\end{array}$ \\
\hline $\begin{array}{l}{ }^{*} \text { Bruijn et al. }(2010)^{28} \\
\text { Netherlands }\end{array}$ & $\begin{array}{l}\text { Crossover RCT } \\
\text { (Non-industry funded) }\end{array}$ & $\begin{array}{l}\text { Children (6-13 years) with migraine (with or } \\
\text { without aura) with history of } \geq 2 \text { or more } \\
\text { migraine attacks per month, some also suffering } \\
\text { from tension-type headache } \\
\text { (Not reported) }\end{array}$ & 42 & $\begin{array}{l}50 \mathrm{mg} \text { vitamin B2 vs. } \\
\text { Placebo } \\
\text { (Once daily for } 16 \text { weeks) }\end{array}$ & $\begin{array}{l}\text { Migraine severity, } \\
\text { frequency, and duration }\end{array}$ \\
\hline $\begin{array}{l}\text { Lea et al. }(2009)^{29} \\
\text { Australia }\end{array}$ & $\begin{array}{l}\text { Parallel RCT } \\
\text { (Non-industry funded) }\end{array}$ & $\begin{array}{l}\text { Long time ( }>20 \text { years) Caucasian adult patients } \\
\text { with migraine (with aura }>90 \% \text { of their } \\
\text { attacks), with at least four attacks lasting more } \\
\text { than } 48 \mathrm{~h} \text {, a family history of migraine, and } \\
\text { outcome confirmed by a neurologist } \\
(25 \%)\end{array}$ & 52 & $\begin{array}{l}\text { Multivitamin ( } 2 \mathrm{mg} \text { folic } \\
\text { acid, } 25 \mathrm{mg} \text { vitamin B6, } \\
\text { and } 400 \mathrm{mg} \mathrm{B} 12 \text { ) vs. } \\
\text { Placebo } \\
\text { (Once daily for } 6 \text { months) }\end{array}$ & $\begin{array}{l}\text { Migraine severity, } \\
\text { frequency, and migraine } \\
\text { associated disability }\end{array}$ \\
\hline $\begin{array}{l}{ }^{*} \text { Mahdavi et al. }(2009)^{30} \\
\text { Iran }\end{array}$ & $\begin{array}{l}\text { Parallel RCT } \\
\text { (Non-industry funded) }\end{array}$ & $\begin{array}{l}\text { Migraine patients (18-65 years) and history of } \\
\text { migraine headache more than } 1 \text { year } \\
(22.1 \%)\end{array}$ & 95 & $\begin{array}{l}250 \mathrm{mg} \text { magnesium vs. } \\
\text { Placebo(Twice daily for } \\
12 \text { weeks) }\end{array}$ & $\begin{array}{l}\text { Migraine severity, } \\
\text { frequency, and days with } \\
\text { migraine }\end{array}$ \\
\hline $\begin{array}{l}\text { MacLennan et al. }(2008)^{31} \\
\text { Australia }\end{array}$ & $\begin{array}{l}\text { Parallel RCT } \\
\text { (Not reported) }\end{array}$ & $\begin{array}{l}\text { Children ( } 5-15 \text { years) with migraine (with or } \\
\text { without aura), with at least } 3 \text { months history of } \\
\text { migraine of at least } 2-8 \text { days per month } \\
(50 \%)\end{array}$ & 53 & $\begin{array}{l}200 \mathrm{mg} \text { vitamin B2 vs. } \\
\text { Placebo } \\
\text { (Once daily for } 12 \text { weeks) }\end{array}$ & $\begin{array}{l}\text { Migraine frequency and } \\
\text { adverse events }\end{array}$ \\
\hline $\begin{array}{l}{ }^{*} \text { Koseoglu et al. }(2008)^{32} \\
\text { Turkey }\end{array}$ & $\begin{array}{l}\text { Parallel RCT } \\
\text { (Not reported) }\end{array}$ & $\begin{array}{l}\text { Patients ( } 20-55 \text { years) with at least } 2 \text { years of } \\
\text { migraine (without aura) } \\
(12.5 \%)\end{array}$ & 40 & $\begin{array}{l}300 \mathrm{mg} \text { magnesium vs. } \\
\text { Placebo } \\
\text { (Twice daily for } 3 \text { months) }\end{array}$ & $\begin{array}{l}\text { Migraine severity and } \\
\text { frequency }\end{array}$ \\
\hline $\begin{array}{l}\text { * Sandor et al. }(2005)^{33} \\
\text { Switzerland }\end{array}$ & $\begin{array}{l}\text { Parallel RCT } \\
\text { (Industry funded) }\end{array}$ & $\begin{array}{l}\text { Migraine (with or without aura) patients }(18-65 \\
\text { years), with a migraine history } \geq 1 \text { year, two to } \\
\text { eight attacks per month } \\
(18.6 \%)\end{array}$ & 43 & $\begin{array}{l}100 \text { mg coenzyme Q10 vs. } \\
\text { Placebo } \\
\text { (Three times daily for } 3 \\
\text { months) }\end{array}$ & $\begin{array}{l}\text { Migraine severity, } \\
\text { frequency, duration, } \\
\text { days with migraine, and } \\
\text { adverse events }\end{array}$ \\
\hline $\begin{array}{l}{ }^{*} \text { Wang et al. }(2003)^{34} \\
\text { USA }\end{array}$ & $\begin{array}{l}\text { Parallel RCT } \\
\text { (Non-industry funded) }\end{array}$ & $\begin{array}{l}\text { Children and adolescents ( } 3-17 \text { years) with } \\
\text { migraine, weighing less than } 197 \text { pounds, with a } \\
\text { history of at least weekly, moderate to severe } \\
\text { migraine headaches during the } 4 \text { weeks to } \\
\text { recruitment } \\
(31.4 \%)\end{array}$ & 118 & $\begin{array}{l}9 \mathrm{~kg} / \mathrm{kg} \text { body weight/day } \\
\text { magnesium vs. Placebo } \\
\text { (Three times daily for } 16 \\
\text { weeks) }\end{array}$ & Adverse events \\
\hline
\end{tabular}


Table 1: (Continued)

\begin{tabular}{|c|c|c|c|c|c|}
\hline Trial and Country & $\begin{array}{c}\text { Trial Design } \\
\text { (Funding Source) }\end{array}$ & Trial Population (Percentage of males) & $\begin{array}{l}\text { No. of } \\
\text { Patients }\end{array}$ & $\begin{array}{c}\text { Interventions Compared } \\
\text { (Frequency and } \\
\text { Duration) }\end{array}$ & $\begin{array}{l}\text { Outcomes } \\
\text { Assessed }\end{array}$ \\
\hline $\begin{array}{l}{ }^{*} \text { Schoenen et al. }(1998)^{35} \\
\text { Belgium }\end{array}$ & $\begin{array}{l}\text { Parallel RCT } \\
\text { (Non-industry funded) }\end{array}$ & $\begin{array}{l}\text { Migraine (with or without aura) patients (18-65 } \\
\text { years) with at least one migraine attack during } \\
\text { the preceding month, and had between two and } \\
\text { eight attacks per month } \\
(22.2 \%)\end{array}$ & 55 & $\begin{array}{l}400 \mathrm{mg} \text { vitamin B2 vs. } \\
\text { Placebo } \\
\text { (Once daily for } 3 \text { months) }\end{array}$ & $\begin{array}{l}\text { Migraine severity, } \\
\text { frequency, duration, } \\
\text { days with migraine, and } \\
\text { adverse events }\end{array}$ \\
\hline $\begin{array}{l}{ }^{*} \text { Peikert et al. }(1996)^{36} \\
\text { Germany }\end{array}$ & $\begin{array}{l}\text { Parallel RCT } \\
\text { (Not reported) }\end{array}$ & $\begin{array}{l}\text { Migraine (with or without aura) patients (18-65 } \\
\text { years), with mean attack frequency of } 3.6 \text { per } \\
\text { month, and outcome confirmed by a neurologist } \\
(13.6 \%)\end{array}$ & 81 & $\begin{array}{l}24 \mathrm{mmol}(600 \mathrm{mg}) \\
\text { magnesium vs. Placebo } \\
\text { (Once daily for } 12 \text { weeks) }\end{array}$ & $\begin{array}{l}\text { Migraine severity, } \\
\text { frequency, duration, } \\
\text { days with migraine, and } \\
\text { adverse events }\end{array}$ \\
\hline $\begin{array}{l}\text { *Pfaffenrath et al. }(1996)^{37} \\
\text { Austria, Germany, } \\
\text { Switzerland }\end{array}$ & $\begin{array}{l}\text { Parallel RCT } \\
\text { (Not reported) }\end{array}$ & $\begin{array}{l}\text { Migraine (without aura) patients ( } 18-60 \text { years) } \\
\text { with } 2-6 \text { migraine attacks per month in the } \\
\text { previous three months before study and } \geq 2 \\
\text { years of history of migraine, and outcome } \\
\text { confirmed by a neurologist } \\
(7.2 \%)\end{array}$ & 69 & $\begin{array}{l}20 \mathrm{mmol}(500 \mathrm{mg}) \\
\text { magnesium vs. Placebo } \\
\text { (Once daily for } 12 \text { weeks) }\end{array}$ & $\begin{array}{l}\text { Migraine severity, } \\
\text { duration, and adverse } \\
\text { events }\end{array}$ \\
\hline
\end{tabular}

$\mathrm{RCT}=$ randomized controlled trial; ${ }^{*}=$ trials considered in meta-analysis; vs. $=$ versus.

\section{Quality of Evidence}

Two reviewers (GNO and AMAS) assessed the quality of evidence for the main outcomes (migraine frequency and duration of migraine) and migraine severity using the Grading of Recommendations Assessment, Development and Evaluation (GRADE) Working Group methodology. ${ }^{20}$ Disagreements were resolved by discussion between the two reviewers.

\section{Results}

From 5343 citations obtained from all searched sources, we included 18 placebo-controlled trials (17 parallel-design RCTs and 1 crossover design RCT) (Figure 1). ${ }^{21-38}$ One of the included trials is still ongoing. ${ }^{38}$

The 17 completed trials were published from 1996 to 2016. Five of the trials were conducted in Iran, ${ }^{21,23,24,27,30}$ of which two of these were reported in Persian. Four trials were conducted in Australia, ${ }^{22,26,29,31}$ six trials in Europe,$^{25,28,33,35-37}$ and one trial each in the USA, ${ }^{34}$ and Turkey. ${ }^{32}$

The number of participants ranged from 40 to 300 (Table 1). Twelve trials involved only adults, ${ }^{22,24-27,29,30,32,33,35-37}$ three trials involved only children, ${ }^{28,31,34}$ and two trials involved both children and adults. ${ }^{21,23}$ Two trials involved only females ${ }^{22,26}$ and the rest of the 15 involved both males and females. All the trials compared vitamins or minerals (magnesium, ${ }^{27,30,32,34,36,37}$ vitamin B2, ${ }^{28,31,35}$ and coenzyme Q10 (vitamin-like supplement) ${ }^{21,33}$ multivitamins containing folic acid, vitamins B6 and $\mathrm{B} 12,{ }^{22,26,29}$ vitamin $\mathrm{B} 6,{ }^{24}$ vitamin $\mathrm{D},{ }^{23}$ and a multivitamin containing vitamin $\mathrm{B} 2$, magnesium and coenzyme Q10) ${ }^{25}$ against placebo. Utilized doses, dosing frequency, and duration of treatment were comparable across trials for magnesium but varied considerably for vitamins. For example, three trials utilized 500 $\mathrm{mg}$ of oral magnesium once daily or $250 \mathrm{mg}$ twice daily (same as $500 \mathrm{mg}$ daily $)^{27,30,37}$ and two other trials utilized $600 \mathrm{mg}$ of magnesium once daily or $300 \mathrm{mg}$ twice daily, ${ }^{32,36}$ with almost all the trials lasting for 12 weeks. On the other hand, trials on vitamins involving vitamins $\mathrm{B} 2, \mathrm{~B} 6, \mathrm{D}$, or coenzyme Q10 21,23,24,28,31,33,35 used considerably different daily doses, dosing frequency, and duration of treatment, even for trials using the same vitamin.

Measurement of migraine severity was carried out using visual analog scale in six trials, ${ }^{21,23,24,32,36,39}$ 4-point scale in two trials, ${ }^{28,35} 3$-point scale in two trials, ${ }^{25,27}$ a pain score $(1-10)$ scale in one trial, ${ }^{29}$ migraine diary in two trials, ${ }^{22,37}$ and not reported in three trials. ${ }^{26,30,33}$ Two trials were funded by industry, ${ }^{25,33}$ four trials did not report on funding, ${ }^{31,32,36,37}$ and the rest reported non-industry funding. ${ }^{21-24,26-30,34,35}$ Thirteen trials provided data that were considered in the meta-analyses. $^{21,23-25,27,28,30,32-37}$ Results from trials involving adult patients were meta-analyzed separately from those involving pediatric patients. Meta-analysis of results from trials involving pediatric patients was not feasible due to a lack of sufficiently reported data.

\section{Risk of Bias}

We judged a high proportion of the trials to have unclear risk of bias for sequence generation (52.9\%), and unclear or high risk of bias for allocation concealment (76.5\%), incomplete outcome reporting (58.8\%), blinding of participants and personnel (41.2\%), and outcome assessment (52.9\%) (Table 2). Overall, 1 trial was judged to be of low risk, ${ }^{29} 12$ trials of unclear risk, ${ }^{21-23,25,26,28,31,33-35,37}$ and 5 trials of high risk of bias. ${ }^{24,27,30,32,36}$ Supplementary Table 2 summarizes the reasons for the risk of bias judgment decisions.

\section{Primary Outcomes}

\section{Migraine Frequency (per Month)}

Compared with placebo, coenzyme Q10 was found to be associated with a non-statistically significant reduction in migraine frequency (MD -0.44 (95\% CI -2.14 to 1.26$) ; I^{2} 53 \% ; 2$ trials; 97 participants; moderate strength of the evidence; Figure 2) among adults. Due to marked heterogeneity between the included trials for assessment of magnesium ( $I^{2} 88 \%$; 4 trials, 266 participants), we 
Table 2: Risk of bias judgment for included trials

\begin{tabular}{|c|c|c|c|c|c|c|c|}
\hline Trial & Intervention(s) & $\begin{array}{c}\text { Sequence } \\
\text { generation }\end{array}$ & $\begin{array}{c}\text { Allocation } \\
\text { concealment }\end{array}$ & $\begin{array}{c}\text { Blinding of } \\
\text { participants and } \\
\text { personnel }\end{array}$ & $\begin{array}{c}\text { Blinding of } \\
\text { outcome } \\
\text { assessment }\end{array}$ & $\begin{array}{c}\text { Incomplete } \\
\text { outcome data }\end{array}$ & $\begin{array}{l}\text { Selective outcome } \\
\text { reporting }\end{array}$ \\
\hline $\begin{array}{l}\text { Khorvash et al. } \\
(2016)^{21}\end{array}$ & Co-Q10 & $?$ & $?$ & + & $?$ & + & + \\
\hline $\begin{array}{l}\text { Menon et al. } \\
(2016)^{22}\end{array}$ & $\begin{array}{c}\text { (Folic acid/Vit. B6, } \\
\text { B12) }\end{array}$ & + & $?$ & + & + & $?$ & + \\
\hline $\begin{array}{l}\text { Mottaghi et al. } \\
(2015)^{23}\end{array}$ & Vit. D & $?$ & $?$ & $?$ & $?$ & $?$ & + \\
\hline $\begin{array}{l}\text { Sadeghi et al. } \\
(2015)^{24}\end{array}$ & Vit. B6 & + & + & + & + & - & + \\
\hline Gaul et al. $(2015)^{25}$ & Vit. B2/Mag./Co-Q10 & + & $?$ & + & + & + & + \\
\hline $\begin{array}{l}\text { Menon et al. } \\
(2012)^{26}\end{array}$ & $\begin{array}{c}\text { (Folic acid/Vit. B6, } \\
\text { B12) }\end{array}$ & + & $?$ & + & + & $?$ & + \\
\hline $\begin{array}{l}\text { Tarighat Esfanjani } \\
\text { et al. }(2012)^{27}\end{array}$ & Mag. & $?$ & - & $?$ & - & + & + \\
\hline Bruijn et al. $(2010)^{28}$ & Vit. B2 & $?$ & $?$ & + & + & + & + \\
\hline Lea et al. $(2009)^{29}$ & $\begin{array}{c}\text { (Folic acid/Vit. B6, } \\
\text { B12) }\end{array}$ & + & + & + & + & + & + \\
\hline $\begin{array}{l}\text { Mahdavi et al. } \\
(2009)^{30}\end{array}$ & Mag. & $?$ & $?$ & - & - & - & + \\
\hline $\begin{array}{l}\text { MacLennan et al. } \\
(2008)^{31}\end{array}$ & Vit. B2 & + & $?$ & + & + & + & + \\
\hline Koseoglu $(2008)^{32}$ & Mag. & $?$ & - & $?$ & $?$ & + & + \\
\hline $\begin{array}{l}\text { Sandor et al. } \\
(2005)^{33}\end{array}$ & Co-Q10 & + & + & $?$ & $?$ & $?$ & + \\
\hline Wang et al. $(2003)^{34}$ & Mag. & + & $?$ & + & + & $?$ & + \\
\hline $\begin{array}{l}\text { Schoenen et al. } \\
(1998)^{35}\end{array}$ & Vit. B2 & $?$ & + & + & $?$ & $?$ & + \\
\hline $\begin{array}{l}\text { Peikert et al. } \\
(1996)^{36}\end{array}$ & Mag. & $?$ & - & $?$ & - & $?$ & + \\
\hline $\begin{array}{l}\text { Pfaffenrath et al. } \\
(1996)^{37}\end{array}$ & Mag. & $?$ & $?$ & $?$ & $?$ & $?$ & + \\
\hline
\end{tabular}

Co-Q10 = Coenzyme Q10; Vit. = Vitamin; Mag = Magnesium; vs = Versus

decided not to present the result of the pooled analysis although a statistically significantly associated reduction in migraine frequency was found among adults. The effect estimates ranged from -2.57 to -0.93 . Our sensitivity analyses and examination of the trial characteristics did not resolve potential sources of heterogeneity. There was only one trial on vitamin B2 and it reported a statistically significant reduction in migraine frequency for vitamin B2 among adults (Table 3). Assessment of other vitamins and minerals was not feasible due to a lack of sufficiently reported data. There were two trials in pediatric patients and both examined vitamin B2. Only one trial reported analyzable data and the result showed no association between vitamin B2 and migraine frequency (Table 3).

\section{Migraine Duration (Hours)}

Compared with placebo, coenzyme Q10 was associated with a non-statistically significant reduction in migraine duration (MD -1.97 (95\% CI -4.82 to 0.87 ); $I^{2} 0 \%$; 2 trials; 97 participants; moderate strength of the evidence; Figure 3 ) among adults. There was only one trial each for magnesium and vitamin B2 assessments, and only the latter had an association with a statistically significant reduction in migraine duration among adults (Table 3 ). Assessment of other vitamins and minerals was not feasible due to a lack of sufficiently reported data. There was only one trial in pediatric patients and the trial reported no association between vitamin B2 and migraine duration (Table 3).

\section{Secondary Outcomes}

\section{Migraine Severity}

Compared with placebo, magnesium and coenzyme Q10 were each non-statistically significantly associated with a reduction in migraine severity among adults (RoM -0.17 (95\% CI -0.36 to 0.02); $I^{2} 48 \%$; 3 trials; 226 participants; low strength of the evidence) and (RoM -0.05 (95\% CI -0.20 to 0.11$) ; I^{2} 0 \% ; 2$ trials; 97 participants; moderate strength of the evidence), respectively (Supplementary Figure 1). We found only one trial on vitamin B2 and migraine severity, and the trial reported no association for adults. Assessment of other vitamins and minerals was not feasible due to a lack of sufficiently reported data. 


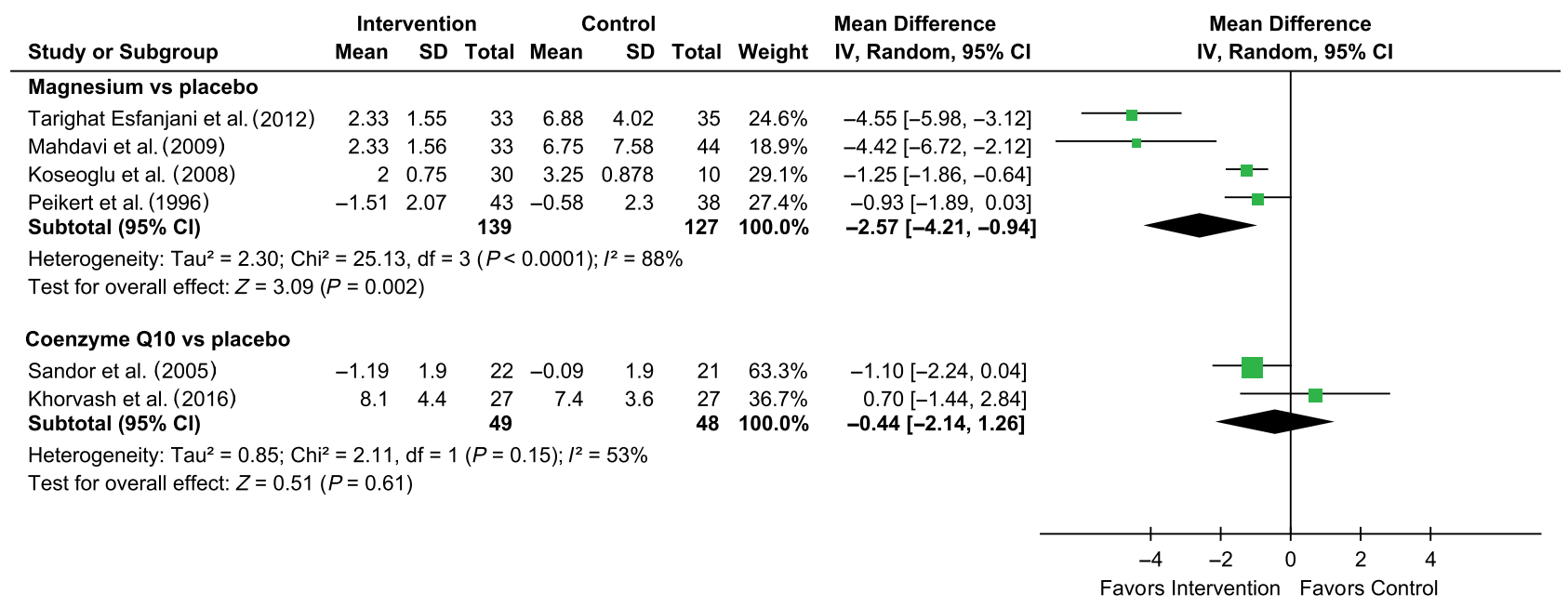

Figure 2: Forest plot for migraine frequency. Only one trial on vitamin B2 (MD -2.00 (-2.60 to -1.40)) - not included in the forest plot.

Irrespective of intervention type, there was no difference in pooled analysis between trials among adults with high and unclear risk of bias; both were associated with statistically significant reductions in migraine severity (Table 3). Measurements of migraine severity among adults using the visual analog scale or the 3-point scale were associated with statistically significant reductions in migraine severity irrespective of intervention type (Table 3 ). There was only one trial in pediatric patients and the trial reported no association between vitamin B2 and migraine severity (Table 3).

\section{Days with Migraine}

Compared with placebo, magnesium was found to be statistically significantly associated with a reduction in days with migraine among adults but with marked unexplained heterogeneity $\left(I^{2} 87 \%\right.$; Supplementary Figure 2). There was only one trial each on vitamin B2 and coenzyme Q10; only the former was found to be statistically significantly associated with a reduction in days with migraine and the latter showed a non-statistically significant association. Assessment of vitamins and other minerals was not feasible due to a lack of sufficiently reported data. Results of subgroup analysis are shown in Supplementary Table 3. There were no trials in pediatric patients reporting on the number of days with migraine.

\section{Adverse Events}

Adverse events examined in included trials among adults were mainly gastrointestinal side effects, for example, diarrhea, nausea, gastric irritation, vomiting, and soft stool. Assessment of individual vitamins and minerals was not feasible due to a lack of data. Two trials provided data appropriate for meta-analysis but these trials assessed different intervention; therefore, their data were not pooled. There were two trials in pediatric patients reporting on adverse events. One trial examined vitamin B2 and the other examined magnesium. Only one trial reported analyzable data and the result showed no association between vitamin B2 and migraine adverse events.

\section{Discussion}

In this systematic review and meta-analysis examining the use of vitamins and minerals for migraine prophylaxis, coenzyme
Q10 was found to be non-statistically significantly associated with a reduction in migraine frequency, duration, and severity among adults. Magnesium was also found to be non-statistically significantly associated with a reduction in migraine severity and days with migraine among adults, and although a statistically significantly associated reduction was found with migraine frequency, there was a high level of heterogeneity precluding pooling. However, the larger two trials in the analysis for migraine frequency reported statistically significant associations, whereas the third trial reported no association. Meta-analysis of other vitamins and minerals, and adverse events were not feasible due to a lack of sufficiently reported data.

Potentially insufficient statistical power in some of the analyses as a result of inadequacy of the evidence, variations in the studied populations' age, sex, comorbidity status and type of migraine, study geographical differences, and quality are likely contributors to the observed heterogeneity and the inability to conclusively determine the efficacy of the interventions. Utilized doses, dosing frequency, and duration of treatment with magnesium were comparable across trials. On the other hand, trials on the same vitamin or coenzyme Q10 had considerably differing daily doses, dosing frequency, and duration of treatment. Overall, the majority of the included trials were small (ranging from 40 to 300 patients) and there were underlying differences between the studied populations. For example, they differed in the length of time patients had suffered migraine before enrolment in the trials, migraine type (whether with or without associated aura, and whether patients with menstrual migraine were allowed to be included or not), and proportion of patients with family history of migraine. In addition, there were potential differences in baseline frequency of attacks, average age of study population, patients' comorbidities, socioeconomic status, and social habits such as smoking and alcohol consumption, all of which can influence how well a patient will respond to an intervention. The washout period, if any, was not clearly stated in some of the trials and, in some trials, it was also not clear whether patients were allowed to use pain/acute headache medications (e.g. non-steroidal antiinflammatory drugs) if they needed to do so. Another potential consideration is the different physiologic mechanisms of action of different vitamins and minerals against different migraine 
Table 3: Subgroup meta-analysis for migraine frequency, duration, and severity

\begin{tabular}{|c|c|c|c|}
\hline \multicolumn{4}{|c|}{ Migraine Frequency (per month) } \\
\hline Subgroup & $\begin{array}{l}\text { Number } \\
\text { of trials }\end{array}$ & $\begin{array}{l}\text { Number } \\
\text { analyzed }\end{array}$ & $\begin{array}{c}\text { Effect estimate }(95 \% \mathrm{CI}) ; \\
\text { I-squared statistic for heterogeneity }\end{array}$ \\
\hline Vitamin $\mathrm{B} 2^{35}$ & 1 & 54 & $\mathrm{MD}-2.00(-2.60$ to -1.40$)$ \\
\hline Coenzyme Q10 $0^{21,33}$ & 2 & 97 & MD $-0.44(-2.14$ to 1.26$) ; I^{2}=53 \%$ \\
\hline Vitamins $^{21,23,24,33,35}$ & 5 & 270 & $\mathrm{MD}-1.32(-2.34$ to -0.29$) ; I^{2}=49 \%$ \\
\hline$<18$ years $^{28}$ & 1 & 38 & MD $0.44(-0.91$ to 1.79$)$ \\
\hline Mixed population $^{21,23}$ & 2 & 119 & MD $0.13(-1.64$ to 1.91$) ; I^{2}=0 \%$ \\
\hline Trials with unclear RoB assessment ${ }^{21,23,33,35}$ & 4 & 178 & $\mathrm{MD}-1.19(-2.25$ to -0.12$) ; I^{2}=57 \%$ \\
\hline Industry-funded trials ${ }^{33}$ & 1 & 43 & $\mathrm{MD}-1.10(-2.24$ to 0.04$)$ \\
\hline \multicolumn{4}{|c|}{ Migraine Duration (in hours) } \\
\hline Magnesium $^{36}$ & 1 & 81 & $\mathrm{MD}-0.21(-0.70$ to 0.28$)$ \\
\hline Vitamin $\mathrm{B} 2^{35}$ & 1 & 54 & MD $-1.53(-2.92$ to -0.14$)$ \\
\hline Coenzyme Q10 $10^{21,33}$ & 2 & 97 & MD $-1.97(-4.82$ to 0.87$) ; I^{2}=0 \%$ \\
\hline Vitamins $^{21,23,24,33,35}$ & 5 & 185 & MD $-1.96(-3.54$ to -0.39$) ; I^{2}=14 \%$ \\
\hline Minerals $^{36}$ & 1 & 81 & MD $-0.21(-0.70$ to 0.28$)$ \\
\hline$<18$ years $^{28}$ & 1 & 24 & MD $0.94(-0.17$ to 2.05$)$ \\
\hline$\geq 18$ years $^{24,33,35,36}$ & 4 & 171 & $\mathrm{MD}-0.73(-1.65$ to 0.18$) ; I^{2}=31 \%$ \\
\hline Mixed population $^{21,23}$ & 2 & 119 & MD $-5.19(-12.03$ to 1.66$) ; I^{2}=44 \%$ \\
\hline Trials with unclear RoB assessment ${ }^{24,33,35,36}$ & 4 & 208 & MD $-0.73(-1.65$ to 0.18$) ; I^{2}=31 \%$ \\
\hline Trials with high RoB assessment ${ }^{21,23}$ & 2 & 119 & MD $-5.19(-12.03$ to 1.66$) ; I^{2}=44 \%$ \\
\hline Industry-funded trials ${ }^{33}$ & 1 & 43 & $\mathrm{MD}-2.10(-5.13$ to 0.93$)$ \\
\hline Non-industry-funded trials ${ }^{21,23,24,35,36}$ & 5 & 223 & $\mathrm{MD}-1.20(-2.79$ to 0.39$) ; I^{2}=57 \%$ \\
\hline \multicolumn{4}{|c|}{ Migraine Severity (intensity) } \\
\hline Magnesium $^{27,30,36}$ & 3 & 226 & $\mathrm{ROM}-0.17(-0.36$ to 0.02$) ; I^{2}=48 \%$ \\
\hline Vitamin $\mathrm{B} 2^{35}$ & 1 & 54 & ROM 0.00 (-6.64 to 6.64$)$ \\
\hline Coenzyme Q10 $0^{21,33}$ & 2 & 97 & ROM $-0.05(-0.20$ to 0.11$) ; I^{2}=0 \%$ \\
\hline Vitamins $^{21,23,24,33,35}$ & 5 & 270 & $\mathrm{ROM}-0.13(-0.22$ to -0.03$) ; I^{2}=0 \%$ \\
\hline Minerals $^{27,30,36}$ & 3 & 226 & ROM -0.17 ( -0.36 to 0.02$) ; I^{2}=48 \%$ \\
\hline$<18$ years $^{28}$ & 1 & 27 & ROM $0.26(-0.05$ to 0.57$)$ \\
\hline$\geq 18$ years $^{24,25,27,30,33,35,36}$ & 7 & 428 & $\mathrm{ROM}-0.13(-0.22$ to -0.05$) ; I^{2}=20 \%$ \\
\hline Mixed population $^{21,23}$ & 2 & 119 & $\mathrm{ROM}-0.11(-0.23$ to 0.01$) ; I^{2}=11 \%$ \\
\hline Trials with unclear RoB assessment ${ }^{21,23,25,33,35}$ & 5 & 311 & $\mathrm{ROM}-0.08(-0.15$ to -0.02$) ; I^{2}=0 \%$ \\
\hline Trials with high RoB assessment ${ }^{24,27,30,36}$ & 4 & 280 & ROM $-0.18(-0.30$ to -0.07$) ; I^{2}=24 \%$ \\
\hline Measured by visual analog scale $\mathrm{s}^{21,23,24,36}$ & 4 & 193 & MD $-0.74(-1.21$ to -0.27$) ; I^{2}=0 \%$ \\
\hline Measured by 4 -point scale ${ }^{35}$ & 1 & 54 & $\mathrm{MD}-0.05(-0.38$ to 0.28$)$ \\
\hline Measured by 3-point Scale ${ }^{25,27}$ & 2 & 180 & MD $-0.27(-0.53$ to -0.02$) ; I^{2}=44 \%$ \\
\hline Industry-funded trials ${ }^{25,33}$ & 2 & 155 & ROM $-0.07(-0.15$ to 0.01$) ; I^{2}=0 \%$ \\
\hline Non-industry-funded trials ${ }^{21,23,24,27,30,35,36}$ & 7 & 465 & $\mathrm{ROM}-0.15(-0.23$ to -0.08$) ; I^{2}=2 \%$ \\
\hline
\end{tabular}

$\mathrm{CI}=$ Confidence Interval; ROM $=$ Ratio of Means; MD = Mean Difference; $I^{2}=I$-squared statistic; RoB $=$ Risk of Bias

outcomes in different migraine patient populations. Internal validity of trials is also an important consideration especially as it relates to risk of bias in key assessment domains, for example, blinding of patients and outcome assessors. All of these may influence the reported efficacy of the interventions and could possibly account for the observed heterogeneity in some of the pooled analyses.
To the best of our knowledge, our review is the first to conduct a comprehensive meta-analysis of the available evidence from RCTs on vitamins and minerals for migraine prophylaxis. A previous review compared oral magnesium with either placebo or an active intervention and reported a significant reduction in the frequency and severity of migraine with oral magnesium but with very high heterogeneity, which the study authors ignored and 


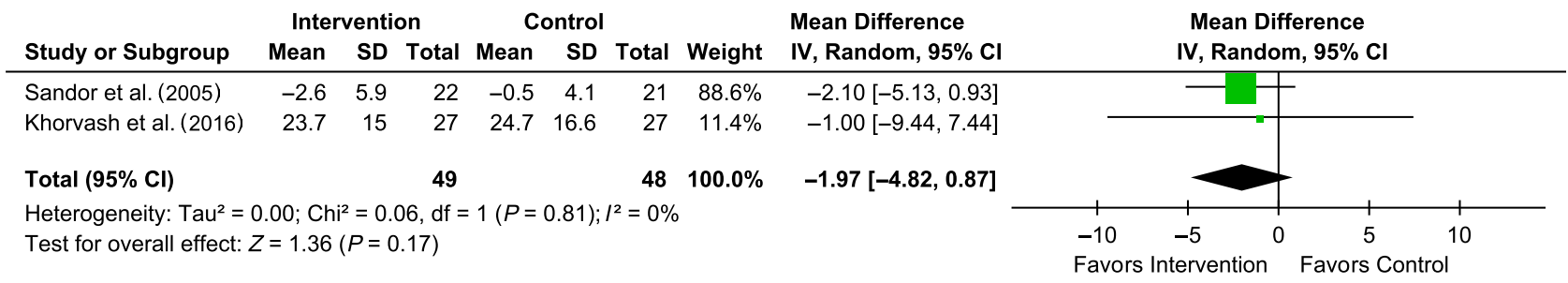

Figure 3: Forest plot for migraine duration. Only one trial each on vitamin B2 (MD -1.53 (-2.92 to -0.14)) and magnesium (MD -0.21 $(-0.70$ to 0.28$))$ - not included in the forest plot.

failed to explore. ${ }^{40}$ In comparison, our review did not include active interventions as comparators. A recent systematic review concluded that vitamin B2 is efficacious in reducing adult patients' migraine frequency but had a mixed effect in pediatric and adolescent patient populations. ${ }^{41}$ However, the conclusions were not based on metaanalysis but rather on narrative summary of the results of 11 trials, some of which did not compare vitamin B2 against placebo or no treatment but against prescription medications. A narrative review of 30 observational studies and RCTs involving vitamin B2, magnesium, coenzyme Q10, and butterbur for pediatric and adult migraine prophylaxis reported no specific conclusions on efficacy; although the authors made weak recommendations in favor of magnesium, coenzyme Q10, and butterbur for pediatric migraine. ${ }^{42}$ There have also been other reviews (without meta-analysis) of vitamins and minerals for migraine prophylaxis and all suggested that these interventions are effective. . $^{2,43,44}$

Our systematic review has its strengths and weaknesses. We registered the review protocol a priori in PROSPERO, conducted the review in accordance with the MECIR guidelines, ${ }^{10}$ and reported as per the PRISMA guidelines. ${ }^{11} \mathrm{We}$ employed a unique approach (the RoM statistic) to pool the results from all trials that utilized different measurement scales for migraine severity. Pooling the results together using MD or standardized MD statistics would not have been appropriate because the statistics do not account for variations in measurement scales, and combination of data from post-treatment means and change scores, respectively. Our inabilities to examine all or most of the a priori determined vitamins/minerals, to conduct subgroup analyses, and to explore the reason(s) for the observed heterogeneity in some of the meta-analyses are limitations to this review. This was, however, due to the unavailability or insufficiency of reporting of trials. Additionally, almost all of the available trials were judged to be of unclear to high risk of bias.

Our findings may not be applicable to all migraine adult patient populations but it is evidence that the efficacy of vitamins and minerals for migraine prophylaxis in adults is not yet established. As such, physicians and migraine patients should be cautious in using and relying on these supplements for migraine prophylaxis. Public health messages should also emphasize the fact that available evidence is poor and inconclusive. Given the low number of RCTs and the low quality of the available evidence, larger and higher quality trials are required in order to draw conclusions on efficacy of vitamins and minerals for migraine prophylaxis.

\section{Conclusions}

Based on the available but insufficient evidence, it is unknown if coenzyme Q10 and magnesium are effective for migraine prophylaxis in adults. It is important to note that the available evidence is of low to moderate strength and from trials with substantial risk of bias. High-quality, adequately powered RCTs are needed to fully evaluate the efficacy and safety of vitamins and minerals to be able to make clinical recommendations on their use for migraine prophylaxis.

\section{Statement of Authorship}

GNO and AMAS conceived and designed the study. CN designed and carried out search strategy for literature. GNO, AMAS, RR, and CN developed study protocol. GNO, HHK, and AKW carried out literature sifting, data extraction, and risk of bias assessment. GNO AMAS, RR, RZ, and BM analyzed the data and interpreted the results. GNO drafted initial manuscript. GNO, AMAS, RZ, and BM provided scientific critique. All authors reviewed and contributed to the final version of the manuscript. GNO coordinated the study.

\section{ACKNOWLEDGEMENTS}

We thank Professor Lyn Griffiths and Drs. Parisa Gazerani, Shirley Wee, and Bridget Maher for responding kindly to our request for additional information regarding their trials. We also thank Dr. David Lightfoot (Health Sciences Library, St. Michael's Hospital, Toronto, Canada) for peer reviewing the MEDLINE search strategy.

\section{Disclosures}

Dr. Zarychanski is a recipient of the new investigator salary award from the Canadian Institutes of Health Research. Dr. Mansouri has received previous research funding from Allergan Canada Ltd. All other authors declare that they have no competing interests. The primary and corresponding author had full access to data presented in this systematic review and all the authors had final responsibility for the decision to submit a manuscript for publication.

\section{Funding}

No funding was attained for this project.

\section{Supplementary Material}

To view supplementary material for this article, please visit https://doi.org/10.1017/cjn.2018.394.

\section{REFERENCES}

1. Pringsheim T, Davenport WJ, Mackie G, et al. Introduction to the guideline, and general principles of migraine prophylaxis - section I. Can J Neurol Sci. 2012;39:S3-7. 
2. Sun-Edelstein C, Mauskop A. Foods and supplements in the management of migraine headaches. Clin J Pain. 2009;25:446-52.

3. Shaik MM, Gan SH. Vitamin supplementation as possible prophylactic treatment against migraine with aura and menstrual migraine. Biomed Res Int. 2015;2015:469529.

4. Mottaghi T, Khorvash F, Askari G, et al. The relationship between serum levels of vitamin D and migraine. J Res Med Sci. 2013;18: S66-70.

5. Janiri L, Gallo G, Nicoletti W. Calcium deficiency and supraorbital headache - a clinical-study of adult subjects. Cephalalgia. 1986;6:211-8.

6. Tepper D. Magnesium. J Head Face Pain. 2013;53:1533-4.

7. Mauskop A, Varughese J. Why all migraine patients should be treated with magnesium. J Neural Transm. 2012;119:575-9.

8. Colombo B, Saraceno L, Comi G. Riboflavin and migraine: the bridge over troubled mitochondria. Neurol Sci. 2014;35(Suppl 1):141-4.

9. Scientific Committee on Food and Scientific Panel on Dietetic Products, Nutrition and Allergies. Tolerable upper intake levels for vitamins and minerals. EU European Food Safety Authority; 2006. pp. 1-482.

10. Higgins JPT, Lasserson T, Chandler J, Tovey D, Churchill R. Methodological Expectations of Cochrane Intervention Reviews (MECIR). London: Cochrane; 2016.

11. Moher D, Liberati A, Tetzlaff J, Altman DG, for the PRISMA Group. Preferred reporting items for systematic reviews and metaanalyses: the PRISMA statement. BMJ. 2009;339:b2535.

12. McGowan J, Sampson M, Salzwedel DM, Cogo E, Foerster V, Lefebvre C. PRESS peer review of electronic search strategies: 2015 guideline statement. J Clin Epidemiol. 2016;75:40-6.

13. Scottish Intercollegiate Guidelines Network. Search filters: randomised controlled trials. Edinburgh: Healthcare Improvement Scotland; 2015

14. Higgins J, Green S, editors. Cochrane handbook for systematic reviews of interventions, version 5.1.0 [updated March 2011]. The Cochrane Collaboration; 2011. Available at: www. handbook.cochrane.org.

15. (RevMan) RM. Version 5.3. Ed. Copenhagen: The Nordic Cochrane Centre; 2014.

16. Hozo SP, Djulbegovic B, Hozo I. Estimating the mean and variance from the median, range, and the size of a sample. BMC Med Res Methodol. 2005;5:13.

17. Higgins JP, Thompson SG. Quantifying heterogeneity in a metaanalysis. Stat Med. 2002;21:1539-58.

18. Sterne JA, Egger M, Smith GD. Systematic reviews in health care: investigating and dealing with publication and other biases in meta-analysis. BMJ. 2001;323:101-5.

19. Okoli GN, Rabbani R, Neilson C, et al. Vitamin and mineral supplements for migraine prophylaxis: a systematic review and meta-analysis. PROSPERO 2017 CRD42017071440. Available at: http://www.crd.york.ac.il/PROSPERO/display_record.php? $\mathrm{ID}=\mathrm{CRD} 42017071440$.

20. Guyatt G, Oxman AD, Sultan S, et al. GRADE guidelines: 11 . Making an overall rating of confidence in effect estimates for a single outcome and for all outcomes. J Clin Epidemiol. 2013;66:151-7.

21. Khorvash F, Bagheri L, Ghasemi M, Ghaed-Amini A, Maracy MR. Coenzyme q10 in migraine prophylaxis: a randomized, doubleblind, placebo-controlled clinical trial. J Isfahan Med School. 2016;33:1904-11.

22. Menon S, Nasir B, Avgan N, et al. The effect of $1 \mathrm{mg}$ folic acid supplementation on clinical outcomes in female migraine with aura patients. J Headache Pain. 2016;17:60.

23. Mottaghi T, Askari G, Khorvash F, Maracy MR. Effect of Vitamin $\mathrm{D}$ supplementation on symptoms and C-reactive protein in migraine patients. J Res Med Sci. 2015;20:477-82.

24. Sadeghi O, Nasiri M, Maghsoudi Z, Pahlavani N, Rezaie M, Askari G. Effects of pyridoxine supplementation on severity, frequency and duration of migraine attacks in migraine patients with aura: a double-blind randomized clinical trial study in Iran. Iran J Neurol. 2015; $14: 74-80$
25. Gaul C, Diener HC, Danesch U, Migravent ${ }^{\circledR}$ Study Group. Improvement of migraine symptoms with a proprietary supplement containing riboflavin, magnesium and Q10: a randomized, placebo-controlled, double-blind, multicenter trial. J Headache Pain. 2015;16:516.

26. Menon S, Lea RA, Roy B, et al. Genotypes of the MTHFR C677T and MTRR A66G genes act independently to reduce migraine disability in response to vitamin supplementation. Pharmacogenet Genomics. 2012;22:741-9.

27. Tarighat Esfanjani A, Mahdavi R, Ebrahimi Mameghani M, Talebi M, Nikniaz Z, Safaiyan A. The effects of magnesium, L-carnitine, and concurrent magnesium-L-carnitine supplementation in migraine prophylaxis. Biol Trace Elem Res. 2012;150:42-8.

28. Bruijn J, Duivenvoorden H, Passchier J, Locher H, Dijkstra N, Arts WF. Medium-dose riboflavin as a prophylactic agent in children with migraine: a preliminary placebo-controlled, randomised, double-blind, cross-over trial. Cephalalgia. 2010;30: 1426-34.

29. Lea R, Colson N, Quinlan S, Macmillan J, Griffiths L. The effects of vitamin supplementation and MTHFR (C677T) genotype on homocysteine-lowering and migraine disability. Pharmacogenet Genomics. 2009;19:422-8.

30. Mahdavi R, Tarighat Esfanjani A, Ebrahimi M, Talebi M, Ghaem Maghami SJ. Effects of oral magnesium for migraine prophylaxis. Pharm Sci. 2009;15:103-8.

31. MacLennan SC, Wade FM, Forrest KM, Ratanayake PD, Fagan E, Antony J. High-dose riboflavin for migraine prophylaxis in children: a double-blind, randomized, placebo-controlled trial. J Child Neurol. 2008;23:1300-4.

32. Koseoglu E, Talaslioglu A, Gonul AS, Kula M. The effects of magnesium prophylaxis in migraine without aura. Magnesium Res. 2008;21:101-8.

33. Sandor PS, Di Clemente L, Coppola G, et al. Efficacy of coenzyme Q10 in migraine prophylaxis: a randomized controlled trial. Neurology. 2005;64:713-15.

34. Wang F, Van Den Eeden SK, Ackerson LM, Salk SE, Reince RH, Elin RJ. Oral magnesium oxide prophylaxis of frequent migrainous headache in children: a randomized, double-blind, placebocontrolled trial. Headache. 2003;43:601-10.

35. Schoenen J, Jacquy J, Lenaerts M. Effectiveness of high-dose riboflavin in migraine prophylaxis. A randomized controlled trial. Neurology. 1998;50:466-70.

36. Peikert A, Wilimzig C, Kohne-Volland R. Prophylaxis of migraine with oral magnesium: results from a prospective, multi-center, placebo-controlled and double-blind randomized study. Cephalalgia. 1996;16:257-63.

37. Pfaffenrath V, Wessely $\mathrm{P}$, Meyer $\mathrm{C}$, et al. Magnesium in the prophylaxis of migraine - a double-blind placebo-controlled study. Cephalalgia. 1996;16:436-40.

38. Gazerani P. A randomized, parallel, double-blind, placebo-controlled study of vitamin D as prophylactic treatment for migraine. 2012. Available at: https://ClinicalTrials.gov/show/NCT01695460.

39. Slater SK, Nelson TD, Kabbouche MA, et al. A randomized, double-blinded, placebo-controlled, crossover, add-on study of CoEnzyme Q10 in the prevention of pediatric and adolescent migraine. Cephalalgia. 2011;31:897-905.

40. Chiu HY, Yeh TH, Huang YC, Chen PY. Effects of intravenous and oral magnesium on reducing migraine: a meta-analysis of randomized controlled trials. Pain Physician. 2016;19: E97-112.

41. Thompson DF, Saluja HS. Prophylaxis of migraine headaches with riboflavin: a systematic review. J Clin Pharm Ther. 2017; 08:08.

42. Orr SL, Venkateswaran S. Nutraceuticals in the prophylaxis of pediatric migraine: evidence-based review and recommendations. Cephalalgia. 2014;34:568-83.

43. Prousky J, Seely D. The treatment of migraines and tension-type headaches with intravenous and oral niacin (nicotinic acid): systematic review of the literature. Nutr J. 2005;4:3.

44. Sangermani R, Boncimino A. The use of nutraceutics in children's and adolescent's headache. Neurol Sci.2017;38:121-4. 